\title{
Response of Onion to Foliar Spraying with some Nutrients under Different Rates of Npk Fertilizers \\ Mohamed, A. G. ${ }^{1}$; A. M. El-Damarany ${ }^{2}$; R. A. Marey $^{1}$ and S. Gebril ${ }^{2}$ \\ ${ }^{1}$ Onion Research Department, Field Crops Research Institute, Agriculture. Research Center, Giza, Egypt \\ ${ }^{2}$ Department of Horticulture, Faculty of Agriculture, Sohag University, Egypt
}

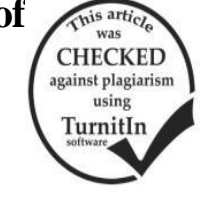

\section{ABSTRACT}

This study was conducted in seasons of 2014/2015 and 2015/2016 at Shandaweel Agriculture Research Station, Sohag, Egypt. The experimental design was randomized complete block design (RCBD) with three replications. The treatments were (1) Nonfertilization, (2). Control treatment (120, 45, $25 \mathrm{~kg} /$ fed NPK), (3). Humic acid $+100 \%$ NPK, (4). Potassin $+100 \%$ NPK, (5) Calfruit + $100 \%$ NPK, (6) Humic acid+ Potassin $+100 \%$ NPK, (7) Humic acid+ Calfruit $+100 \%$ NPK, (8) Potassin + Calfruit + 100\% NPK, (9) Humic acid+ Potassin + Calfruit, (10). Humic acid+ Potassin + Calfruit + 25\% NPK, (11) Humic acid+ Potassin + Calfruit + 50\% NPK (12) Humic acid+ Potassin + Calfruit $+75 \%$ NPK. Application of Pot.+Cal.+HA+75\%NPK, produced the highest values of plant height at 90 and 120 DAT in both seasons and plant dry weight, bulb dry weight at 120 DAT in both seasons. While, Non-fertilization treatment gave the lowest values of plant height, bulb diameter, fresh plant weight, leaves fresh weight, bulb fresh weight, plant dry weight, leaves dry weigh, bulb dry weigh at 90 and 120 DAT and number of days to maturity in the two seasons. Generally, treatment of Pot.+Cal.+HA+75\% NPK attained the highest values of total bulbs yield, bulb diameter, TSS\%, D.M\% in both seasons.

\section{INTRODUCTION}

Onion (Allium cepa, L.), an important vegetable crop in Egypt and the world, is used for exportation, local consumption and processing. In addition, it is an important source for hard currency, due to the early availability of the Egyptian onion for foreign markets as well as its higher quality compared to onion produced in other countries. In Egypt the total cultivated area of onion in 2016 season was 162,833 feddan producing 2,317,707 tons with an average of 14.43 ton/fed (the Yearly Book of Economics and Statistics of the Ministry of Agriculture and Land Reclamation, Egypt, 2017).

The NPK fertilizers applied in the required amounts are essential for producing high yields with a good storage quality. Nitrogen is correlated with chlorophyll content and is an essential for synthesis of amino acids, proteins and enzymes. Phosphorus and potassium are important in multiple physiological processes such photosynthesis, plant metabolism, and enhancing the translocation of photo assimilates Marschner (1995), El-Desuki et al. (2006 a \& b). Because onion has shallow roots with high nutrients demand, and long growing season, it is sensitive to nutritional imbalance Yaso et al. (2007).

Calcium is a major plant nutrient. It is required for the cell wall and membranes integrity and maintenance. Calcium is a counter-cation for inorganic and organic anions White and Broadley (2003). Fertilization with $\mathrm{CaCl}_{2}$ has been shown to improve onion storability through the firmness of the scales Coolong and Randle (2008). Foliar spraying of potassium nitrate and calcium nitrate plus potassium chloride results in the highest vegetative growth and significant reduction of the flaking rate during storage and increases the exportable bulbs percentage.

The objective of this investigation is to study the effect of foliar spraying with some commercial fertilizers products rich in humic acid, calcium and potassium under different rates of NPK fertilization on plant growth, yield and quality of onion crop.

\section{MATERIALS AND METHODS}

This investigation was conducted at Shandaweel Research Station, Agricultural Research Center (ARC) during winter seasons of 2014/2015 to 2015/2016. The site soil class was clay. The area specified for the experiment was left uncultivated in the previous summer in the two seasons.
The physical and chemical analyses of the experimental sites soil are presented in Table (1).

The plot size was $3.5 \mathrm{~m}$ in length and $3 \mathrm{~m}$ in width including five ridges with $60 \mathrm{~cm}$ a part with total area of 10.5 $\mathrm{m}^{2}$. Ridging direction was north-south (NS). Transplants were placed on both sides of the ridge at $7 \mathrm{~cm}$ between plants. The soil received the full doses of Super-phosphate $\left(15.5 \% \mathrm{P}_{2} \mathrm{O}_{5}\right)$ and potassium sulphate $\left(50 \% \mathrm{~K}_{2} \mathrm{O}\right)$ during the soil preparation, while ammonium nitrate $(33.5 \% \mathrm{~N})$, was applied at two equal additions. One addition was after one month and the second addition was after two months from planting date.

Table 1. The mechanical and chemical analysis of the experimental sites soil in both seasons.

\begin{tabular}{|c|c|c|c|}
\hline \multirow{2}{*}{ Determination } & \multirow[b]{3}{*}{ Textural class } & \multicolumn{2}{|c|}{ Season } \\
\hline & & $2014 / 2015$ & $2015 / 2016$ \\
\hline Physical analysis & & Clay loam & Clay loam \\
\hline \multirow{6}{*}{$\begin{array}{l}\text { Chemical } \\
\text { analysis }\end{array}$} & $\mathrm{Ph}$ & 7.8 & 7.7 \\
\hline & $\mathrm{EC}$ (m.mhos $/ \mathrm{cm})$. & 0.84 & 0.73 \\
\hline & Organic matter $\%$ & 1.53 & 1.60 \\
\hline & Available N ppm & 18.20 & 20.00 \\
\hline & Available P ppm & 9.6 & 9.00 \\
\hline & Available K ppm & 273 & 257 \\
\hline \multirow{4}{*}{$\begin{array}{l}\text { Cations } \\
\text { (meq/100g) }\end{array}$} & $\mathrm{Ca}$ & 7.00 & 6.59 \\
\hline & $\mathrm{Mg}$ & 2.9 & 2.38 \\
\hline & $\mathrm{Na}$ & 1.50 & 1.58 \\
\hline & $\mathrm{K}$ & 0.24 & 0.33 \\
\hline \multirow{4}{*}{$\begin{array}{l}\text { Anion } \\
\text { (meq/100g) }\end{array}$} & $\mathrm{CO}_{3}$ & 0.00 & 0.00 \\
\hline & $\mathrm{HCO}_{3}$ & 2.8 & 2.5 \\
\hline & $\mathrm{SO}_{4}$ & 5.5 & 5.3 \\
\hline & $\mathrm{Cl}$ & 3.3 & 3.08 \\
\hline \multirow{4}{*}{$\begin{array}{l}\text { Available } \\
\text { nutrients (ppm) }\end{array}$} & $\mathrm{Fe}$ & 10 & 9.4 \\
\hline & $\mathrm{Cu}$ & 0.47 & 0.45 \\
\hline & $\mathrm{Zn}$ & 1.77 & 1.56 \\
\hline & Mn & 1.00 & 1.01 \\
\hline
\end{tabular}

The onion seeds were sown in the nursery on 25 August and $1^{\text {st }}$ September in the first and second seasons respectively. Nursery bed was prepared and planted with onion seeds (cv. Shandaweel 1) and transplanting took place on $8^{\text {th }}$ November in both seasons. The experimental design was randomized complete blocks design (RCBD) with three replications; the treatments were factorial combination between the NPK chemical fertilizers applied to soil and the foliar application of Humic acid, Potassin and Calfruit. Potassin and Humic acid (General Organization for Agricultural Equalization Fund, Ministry of Agriculture and Land Reclamation, Egypt). Calfruit is produced by Dakahlia 
group company. Foliar spraying was applied three times after 45, 60 and 75 days from transplanting.

Table 2. The chemical composition and rates of sprayed fertilizers.

\begin{tabular}{lcc}
\hline Compounds & Composition & Spraying rate \\
\hline Humic acid & $5 \% \mathrm{~K} 2 \mathrm{O}$ and $5 \% \mathrm{Ca}$ & $1.5 \mathrm{~cm} /$ liter \\
Potassin & $30 \% \mathrm{~K}_{2} \mathrm{O}$ and $5 \% \mathrm{NO}_{3}$ & $1 \mathrm{~L} /$ Fadden \\
Calfruit & $15 \% \mathrm{Ca}, 9 \% \mathrm{~N}, 6 \% \mathrm{~K} 2 \mathrm{O}$ & $2.25 \mathrm{~cm} /$ liter \\
& and $31 \%$ Legno slophonat & \\
\hline
\end{tabular}

The treatments can be illustrated as follows:

T1. Non-fertilization.

T 2. Control (100\% of 120, 45, $24 \mathrm{~kg} / \mathrm{fed} \mathrm{NPK})$.

T 3. Humic acid $+100 \%$ NPK.

T 4. Potasin $+100 \%$ NPK.

T 5. Cal fruit $+100 \%$ NPK

T 6. Humic acid + Potasin $+100 \%$ NPK.

$\mathrm{T}$ 7. Humic acid+ Cal fruit $+100 \%$ NPK.

T 8. Potasin + Cal fruit $+100 \%$ NPK.

T 9. Humic acid + Potasin. + Cal fruit

T 10 . Humic acid + Potasin + Cal fruit $+25 \%$ NPK.

$\mathrm{T} 11$. Humic acid + Potasin + Cal fruit $+50 \%$ NPK.

$\mathrm{T} 12$. Humic acid + Potasin + Cal fruit $+75 \%$ NPK.

\section{Characters studied:}

A- Vegetative characters: Ten random plants were selected from each plot to measure plant height $(\mathrm{cm})$, number of leaves per plant, plant fresh weight (gm) and plant dry weight (gm) at 90 and 120 days after transplanting (DAT).

B. Number of days to maturity: Maturity was determined based on both softening of bulb neck and 50\% top-down of bulb leaves of plot plants. It was estimated as the days taken from transplanting to the harvest stage.

C. Bulbs yield and its components:

The following yield parameters were recorded at harvest:

1. Total bulbs yield ( $\mathrm{t} / \mathrm{fed}$.)

2. Exportable bulbs yield ( $\mathrm{t} / \mathrm{fed}$.), was determined as the weight of single bulbs with diameter from 4 to $7 \mathrm{~cm}$ per feddan.

3. Culls bulbs yield ( $\mathrm{t} / \mathrm{fed}$.), was estimated according to the following equation $=\frac{\text { weight of bolters and doubles }}{\text { Total weight of bulbs }} \times 100$
D. Bulbs quality: The following measurements were taken on 10 random plants from each plot.

1- Bulb diameter (cm): was measured by a caliper at widest part of the bulb.

2- Total soluble solids percentage (T.S.S\%), it was determined immediately after harvest by a hand refractometer according to A.O.A.C. (1975).

3- Dry matter percentage (D.M.\%): It was determined by drying plants for four hours at $105^{\circ} \mathrm{C}$ and then at $70^{\circ} \mathrm{C}$ in a drying oven with ventilator, until the weight reaches to a constant value, according to the following formula:

$$
\text { D.M. } \%=\frac{\text { Sample dry weight }}{\text { Sample fresh weight }} x 100
$$

Statistical analysis:

Statistical analysis was done as described by Snedecor and Cochran (1973). To compare between means, L.S.D. at 0.05 level of significance was used according to Walter and Duncan (1969).

\section{RESULTS AND DISCUSSION}

\section{A. Vegetative growth characteristics:}

Vegetative growth of onion plant expressed as plant height, number of leaves/plant, plant fresh weight and plant dry weight were significantly affected by the fertilization treatments at growth stages of 90 and 120 DAT, in both seasons, except for plant dry weigh at 90 DAT in the second season. (Table 3).

Application of Pot.+Cal.+ HA+75\% NPK gave the highest values of plant height at 90 and 120 DAT in both seasons; plant fresh weight at 90 DAT in the first season and at 120 DAT in both seasons; number of leaves/plant at 120 DAT in the first season; plant fresh weight at 90 DAT in the first season and at 120 days in both seasons; and plant dry weight at 120 DAT in both seasons This treatment surpassed all the other fertilization treatments, which had the different combinations between NPK doses and foliar spraying with humic, potassium and calcium. The treatments of $100 \%$ NPK and Pot. + Cal. $+100 \%$ NPK produced the highest plant dry weight at 90 DAT in the first and second season, respectively, while applying the treatment of $\mathrm{Cal}+100 \%$ NPK produced the highest plant dry weight at 120 DAT in the first season.

Table 3. Response of vegetative growth characteristics of onion to foliar spraying with some nutrients under different rates of NPK fertilizers at 90 and 120 DAT in 2014/2015.

\begin{tabular}{|c|c|c|c|c|c|c|c|c|}
\hline \multirow[b]{2}{*}{ Treatments } & \multicolumn{3}{|c|}{90 DAT } & \multirow[b]{2}{*}{$\begin{array}{c}\text { Plant dry } \\
\text { weight (g) }\end{array}$} & \multicolumn{4}{|c|}{120 DAT } \\
\hline & $\begin{array}{c}\text { Plant } \\
\text { Height }(\mathrm{cm})\end{array}$ & $\begin{array}{c}\text { No. of } \\
\text { Leaves /plant }\end{array}$ & $\begin{array}{l}\text { Plant fresh } \\
\text { weight (g) }\end{array}$ & & $\begin{array}{c}\text { Plant } \\
\text { Height }(\mathrm{cm})\end{array}$ & $\begin{array}{c}\text { No. of } \\
\text { leaves /plant }\end{array}$ & $\begin{array}{c}\text { Plant fresh } \\
\text { weight (g) }\end{array}$ & $\begin{array}{l}\text { Plant dry } \\
\text { weight (g) }\end{array}$ \\
\hline Non-fertilization & 68.67 & 5.97 & 65.56 & 4.09 & 68.33 & 7.33 & 111.11 & 10.33 \\
\hline $100 \%$ NPK (Control) & 81.20 & 7.50 & 69.41 & 6.59 & 84.30 & 7.83 & 169.44 & 15.71 \\
\hline $\mathrm{HA}+100 \%$ NPK & 80.93 & 7.73 & 106.67 & 5.08 & 84.20 & 8.53 & 152.78 & 14.08 \\
\hline Po+100 \% NPK & 79.10 & 6.87 & 95.56 & 6.20 & 80.10 & 8.13 & 161.11 & 14.08 \\
\hline $\mathrm{Cal}+100 \% \mathrm{NPK}$ & 80.10 & 7.40 & 96.44 & 6.31 & 81.77 & 8.30 & 157.22 & 15.77 \\
\hline $\mathrm{HA}+\mathrm{Po}+100 \% \mathrm{NPK}$ & 81.33 & 7.97 & 98.33 & 6.48 & 85.67 & 8.07 & 151.67 & 14.49 \\
\hline $\mathrm{HA}+\mathrm{Cal}+100 \% \mathrm{NPK}$ & 79.53 & 7.73 & 91.67 & 5.56 & 82.70 & 7.93 & 155.00 & 13.89 \\
\hline $\mathrm{Po}+\mathrm{Cal}+100 \% \mathrm{NPK}$ & 78.20 & 7.40 & 66.67 & 5.96 & 84.07 & 8.07 & 160.00 & 15.32 \\
\hline $\mathrm{HA}+\mathrm{Po}+\mathrm{Cal}$ & 82.77 & 6.73 & 91.67 & 5.69 & 78.87 & 7.87 & 147.78 & 13.98 \\
\hline $\mathrm{HA}+\mathrm{Po}+\mathrm{Cal}+25 \% \mathrm{NPK}$ & 81.20 & 6.73 & 96.11 & 6.28 & 83.00 & 7.50 & 155.56 & 14.52 \\
\hline $\mathrm{HA}+\mathrm{Po}+\mathrm{Cal}+50 \% \mathrm{NPK}$ & 83.83 & 7.87 & 108.33 & 4.98 & 84.83 & 8.07 & 172.78 & 15.48 \\
\hline $\mathrm{HA}+\mathrm{Po}+\mathrm{Cal}+75 \% \mathrm{NPK}$ & 84.43 & 7.40 & 111.11 & 6.53 & 87.30 & 8.63 & 180.11 & 15.08 \\
\hline LSD 5\% & 5.65 & 1.03 & 17.11 & 1.11 & 5.99 & 1.05 & 14.00 & 1.63 \\
\hline
\end{tabular}

The results of plant growth characters reflect the role of both humic , potassium and calcium in encouraging onion plants growth and in reducing the needs of plants for NPK fertilization. These results may be due to that humic acid contains nutrients that improve the soil fertility and increase the availability of other nutrients and consequently increase plant growth and yield. It particularly used to reduce the negative effect of salt stress. These results are in line with 
those reported by Hafez (2003), AbdEl-Al et al. (2005), Sheng-li et al. (2010), and Kandil et al. (2013-b). Similar results were obtained by El-Desuki (2004), Sangetha and Singara (2007), Haleema et al. (2012) and Kandil et al.

Table 4. Response of vegetative growth characteristics of onion to foliar spraying with some nutrients under different rates of NPK fertilizers at 90 and 120 DAT in 2015/2016.

\begin{tabular}{|c|c|c|c|c|c|c|c|c|}
\hline \multirow[b]{2}{*}{ Treat. } & \multicolumn{4}{|c|}{90 DAT } & \multicolumn{4}{|c|}{120 DAT } \\
\hline & $\begin{array}{c}\text { Plant } \\
\text { Height (cm) }\end{array}$ & $\begin{array}{c}\text { No. of } \\
\text { leaves /plant }\end{array}$ & $\begin{array}{c}\text { Plant fresh } \\
\text { weight (g) }\end{array}$ & $\begin{array}{l}\text { Plant dry } \\
\text { weight (g) }\end{array}$ & $\begin{array}{c}\text { Plant } \\
\text { Height }(\mathrm{cm})\end{array}$ & $\begin{array}{c}\text { No. of } \\
\text { leaves/plant }\end{array}$ & $\begin{array}{c}\text { Plant fresh } \\
\text { weight (g) }\end{array}$ & $\begin{array}{l}\text { Plant dry } \\
\text { weight (g) }\end{array}$ \\
\hline Non-fertilization & 66.87 & 7.33 & 81.11 & 8.39 & 72.93 & 7.40 & 115.56 & 11.71 \\
\hline $100 \%$ NPK (Control) & 78.87 & 8.00 & 111.11 & 9.54 & 93.67 & 8.27 & 174.44 & 15.33 \\
\hline $\mathrm{HA}+100 \%$ NPK & 76.23 & 8.53 & 125.56 & 11.28 & 94.20 & 9.13 & 169.44 & 16.78 \\
\hline Po+100 \% NPK & 80.87 & 8.55 & 121.67 & 10.48 & 91.87 & 8.73 & 160.11 & 15.89 \\
\hline $\mathrm{Cal}+100 \% \mathrm{NPK}$ & 74.57 & 8.40 & 96.67 & 7.34 & 77.20 & 8.70 & 149.11 & 17.01 \\
\hline $\mathrm{HA}+\mathrm{Po}+100 \% \mathrm{NPK}$ & 78.20 & 8.77 & 107.22 & 9.87 & 94.63 & 8.27 & 172.78 & 16.60 \\
\hline $\mathrm{HA}+\mathrm{Cal}+100 \% \mathrm{NPK}$ & 80.33 & 8.43 & 97.78 & 9.71 & 82.97 & 8.50 & 162.89 & 15.29 \\
\hline $\mathrm{Po}+\mathrm{Cal}+100 \% \mathrm{NPK}$ & 80.53 & 8.19 & 103.33 & 12.78 & 80.97 & 8.57 & 162.89 & 14.67 \\
\hline $\mathrm{HA}+\mathrm{Po}+\mathrm{Cal}$ & 76.33 & 8.43 & 96.11 & 9.79 & 87.00 & 8.47 & 155.11 & 14.36 \\
\hline $\mathrm{HA}+\mathrm{Po}+\mathrm{Cal}+25 \% \mathrm{NPK}$ & 78.33 & 8.50 & 105.56 & 9.92 & 81.77 & 8.97 & 161.33 & 16.02 \\
\hline $\mathrm{HA}+\mathrm{Po}+\mathrm{Cal}+50 \% \mathrm{NPK}$ & 81.07 & 8.40 & 103.33 & 10.24 & 88.27 & 8.77 & 177.22 & 15.80 \\
\hline $\mathrm{HA}+\mathrm{Po}+\mathrm{Cal}+75 \% \mathrm{NPK}$ & 84.77 & 8.56 & 108.33 & 10.04 & 95.33 & 8.83 & 187.78 & 17.77 \\
\hline LSD 5\% & 5.73 & 0.89 & 13.05 & NS & 4.57 & 0.97 & 10.70 & 1.89 \\
\hline
\end{tabular}

The treatments that contained NPK plus potassium and calcium showed higher values in most plant growth characters as compared to NPK alone. Similar results were reported by El-Bassiony (2006), Ghoname et al. (2007) Nabi et al. (2010) and Shaheen et al. (2013) who found that application of calcium and potassium as individually and/or mixing together resulted enhancing plant growth.

Data also revealed that treatment of $100 \%$ NPK (control) exhibit the superiority to the non-fertilization treatment for all growth traits at the two growth stages, in both seasons. These results are attributed to the role of the nitrogen in plant growth characters, as it enhances number of leaves by its simulative effect on cell division and cell enlargement. As a consequence, the number of leaves and leaf dimensions may increase. Similar observations were reported by Jayathilake et al. (2003), Mondal et al. (2004), Singh and Singh (2004), Nasreen et al. (2007). These results, also, can be explained by the role of phosphorus and potassium in multiple physiological processes such as photosynthesis, carbohydrate metabolism, and enhancing the translocation of assimilates and protein synthesis (Marschner, 1995, El-Desuki et al., 2006 a \& b).

Data also exhibited that non- fertilization treatment showed the lowest values of all growth characters at both growth stages in both seasons, except for plant dry weight at 90 DAT in the second season.

B. Number of days to maturity:

Data in Table (5) point out that number of days to maturity was significantly affected by used fertilization treatments in both seasons. The shortest time for plants to mature (127.33 and 124.33day) were resulted from nonfertilization treatment in the first and second seasons respectively, while The longest time to mature (141.00 and 139.33 day) were resulted from the treatment of Pot.+Cal.+HA+75\% NPK in the first season and second seasons respectively,

Data reveal that foliar spraying with calcium and potassium compounds individually and/or mixing together decreased the number of days to maturity as compared to $100 \%$ NPK alone, except for the treatment of Pot. + Cal. + HA $+75 \%$ NPK. These results were true in both seasons. Similar results were reported by Khalil et al. (2002), Mohamed and Hemida (2004). (2013-b) who found that combined application of recommended dose of inorganic fertilizers and lignite humic acid significantly increased the plant growth characters.

\section{Total bulbs yield and its components:}

Data in Table (5) show that the used fertilization treatments exerted a significant effect on total bulbs yield /fed. in both seasons; and on exportable bulbs yield and culls bulbs yield in the second seasons only. Fertilizing onion plants with Pot. + Cal. +HA+75\% NPK produced the highest total bulbs yield/fed (15.84 and $16.69 \mathrm{t} / \mathrm{fed}$.), while nonfertilization treatment produced the lowest yield/fed (11.19 and $6.50 \mathrm{t} / \mathrm{fed}$.), in the first and second seasons respectively. Data also reveal that using the treatment of $\mathrm{HA}+\mathrm{Po}+$ Cal.+75\% NPK significantly increased total bulbs yield as compared to the treatment of $\mathrm{HA}+\mathrm{Po}+\mathrm{Cal}$. alone in both seasons. Such favorable effect of mineral nitrogen on total bulbs yield might be resulted from quickly providing nitrogen uptake in roots zone which resulted in more vegetative growth. These results are in accordance with that found by Islam et al. (2007), Miah et al. (2005), Mohanty and Das (2001), Morsy et al. (2012) and Kandil et al. (2013-a). Plants that received the treatment of Pot. +Cal.+HA+75\% NPK produced the highest values of exportable bulbs yield/fed (13.62 and $14.28 \mathrm{t} / \mathrm{fed}$.) as compared to all other treatments, while the non-fertilization treatment gave the lowest values of exportable bulb yield (9.88 and 5.28 t/fed.), in the first and second seasons respectively. Similar results were obtained by El-beheidi et al. (2004), Mohamed and Hemida (2004), ElTantawy and El-Beik (2009), Soleymani and Shahrajabian (2012) and Esawy et al. (2015).

The above results reveal to the importance of spraying with humic, potassium and calcium on yield and yield components. For the effect of spraying fertilizers with humic acid, it was found that humic acid could be resulted in an increase in plant photosynthates accumulation and plant photosynthesis rates which led to an enhancement in plant growth. This effect can be attained by improving the soil fertility and increasing the availability of nutrients in soil organic matter, consequently, it increases plant growth and yield. These data are in harmony with those observed by Sangetha and Singara (2007), Haleema et al. (2012) and Bettoni et al. (2016). Concerning calcium role, calcium is an important constituents of plant tissues and has a vital role in maintaining and modulating various cell functions (Gerasopoulos and Drogoudi, 2005; Hepler, 2005 and Ghoname et al., 2007). Several factors controlling Potassium 
uptake by plants from the soil solution including soil texture, moisture conditions, $\mathrm{pH}$, aeration and temperature (Mengel and kirkby, 1980). It was found that potassium supply in the soil is seldom adequate to achieve the important processes like as sugar transport from leaves to bulbs, enzyme activation, protein synthesis and cell extension, which finally determine bulbs yield and quality during growth development (Williams and Kafkafi, 1998; Lester and Jifon, 2007; El-Bassiony, 2006; El-Desuki et al., 2006; Shaheen et al., 2011 and Shaheen et al. 2013).

Table 5. Response of days to maturity, bulb yield and yield components of onion to foliar spraying with some nutrients under different rates of NPK fertilizers in 2014/2015 and 2015/2016 seasons.

\begin{tabular}{|c|c|c|c|c|c|c|c|c|}
\hline \multirow[b]{2}{*}{ Treatments } & \multicolumn{4}{|c|}{$2014 / 2015$} & \multicolumn{4}{|c|}{2015 / 2016} \\
\hline & $\begin{array}{l}\text { Days to } \\
\text { matur. }\end{array}$ & $\begin{array}{c}\text { Total bulbs } \\
\text { yield t/fed }\end{array}$ & $\begin{array}{l}\text { Expo. bulbs } \\
\text { yield t/fed }\end{array}$ & $\begin{array}{c}\text { Culls bulb } \\
\text { weig. t/fed }\end{array}$ & $\begin{array}{l}\text { Days to } \\
\text { matur. }\end{array}$ & $\begin{array}{l}\text { Total bulbs } \\
\text { Yield t/fed }\end{array}$ & $\begin{array}{c}\text { Exp. bulbs } \\
\text { yield t/fed }\end{array}$ & $\begin{array}{l}\text { Culls bulb } \\
\text { weig. t/fed }\end{array}$ \\
\hline Non-fertilization & 127.33 & 11.09 & 9.88 & 1.21 & 124.33 & 6.50 & 5.28 & 1.22 \\
\hline $100 \%$ NPK (Control) & 140.67 & 12.57 & 12.24 & 1.32 & 138.67 & 11.79 & 10.14 & 1.65 \\
\hline $\mathrm{HA}+100 \% \mathrm{NPK}$ & 140.67 & 12.91 & 12.28 & 1.54 & 134.33 & 10.00 & 8.24 & 1.76 \\
\hline Po+100 \% NPK & 140.00 & 14.20 & 12.72 & 1.47 & 130.33 & 9.21 & 7.95 & 1.26 \\
\hline $\mathrm{Cal}+100 \% \mathrm{NPK}$ & 140.00 & 12.85 & 11.52 & 1.33 & 136.67 & 8.30 & 6.52 & 1.77 \\
\hline $\mathrm{HA}+\mathrm{Po}+100 \% \mathrm{NPK}$ & 136.00 & 14.47 & 12.78 & 1.69 & 135.67 & 13.21 & 11.71 & 1.50 \\
\hline $\mathrm{HA}+\mathrm{Cal}+100 \% \mathrm{NPK}$ & 140.33 & 12.05 & 11.17 & 1.88 & 132.00 & 10.08 & 8.13 & 1.96 \\
\hline $\mathrm{Po}+\mathrm{Cal}+100 \% \mathrm{NPK}$ & 139.00 & 14.22 & 12.41 & 1.81 & 136.33 & 10.14 & 8.53 & 1.61 \\
\hline $\mathrm{HA}+\mathrm{Po}+\mathrm{Cal}$ & 139.33 & 12.25 & 11.55 & 1.79 & 134.67 & 10.05 & 8.45 & 1.60 \\
\hline $\mathrm{HA}+\mathrm{Po}+\mathrm{Cal}+25 \% \mathrm{NPK}$ & 140.00 & 13.85 & 12.05 & 1.8 & 133.00 & 16.29 & 14.15 & 1.54 \\
\hline $\mathrm{HA}+\mathrm{Po}+\mathrm{Cal}+50 \% \mathrm{NPK}$ & 139.67 & 14.98 & 13.00 & 1.79 & 134.67 & 16.58 & 14.17 & 1.67 \\
\hline $\mathrm{HA}+\mathrm{Po}+\mathrm{Cal}+75 \% \mathrm{NPK}$ & 141.00 & 15.84 & 13.62 & 2.22 & 139.33 & 16.69 & 14.28 & 2.41 \\
\hline LSD 5\% & 3.87 & 2.18 & NS & NS & 5.48 & 4.95 & 4.38 & 1.20 \\
\hline
\end{tabular}

Data also reveal that the lowest values of culls yield (1.21 and $1.22 \mathrm{t} /$ fed.) were observed under non-fertilization treatment in the first and second seasons respectively. However, the highest values of culls yield/fed (2.22 and 2.41 t/fed.) were recorded from the treatment of Pot.+ Cal $+\mathrm{HA}+75 \% \mathrm{NPK}$ in the $1^{\text {st }}$ and $2^{\text {nd }}$ seasons, respectively (Table 5).

D. Bulb quality:

The result in Table (6) show that fertilization treatments affected significantly on bulb diameter and total soluble solids percentage (TSS\%) in both seasons; and on dry matter\% in the first season only.

The maximum bulb diameter $(6.50$ and $6.53 \mathrm{~cm})$ were recorded with the treatment of $\mathrm{HA}+\mathrm{Po}+\mathrm{Cal} .+75 \%$ NPK, while the minimum diameters of bulbs (4.57 and 4.43 $\mathrm{cm})$ were recorded under non-fertilization treatment, in the first and second seasons respectively. Application of $\mathrm{HA}+\mathrm{Po}$ + Cal. plus $75 \%$ PK, significantly increased bulb diameter as compared with spraying with $\mathrm{HA}+\mathrm{Po}+\mathrm{Cal}$. alone. This effect might be due to that the increase of nutrients elements in the soil stimulation effect of nitrogen on building up new cells and increasing the synthesized compounds which may increase bulb diameter. These findings are in accordance with those recorded by Mohanty and Das (2001), Jayathilake et al. (2003), Abdissa et al. (2011), Mozumder et al. (2007) and Soleymani and Shahrajabian (2012).

The average bulb diameter was increased by applying humic acid with reducing mineral fertilizers might be due to that applying humic acid increased microorganism in the soil, which transforms the ability of mobilizing unavailable forms of nutrients elements to available forms, which improves the plant growth. These results were in agreement with that found by El-Desuki (2004), Kandil et al. (2013-b), Bettoni et al. (2016) and Gala et al. (2016).

For the TSS\% character, data clearly show that treatments of non-fertilization and HA + Po. + Cal. gave the highest T.S.S \% (14.40 and $16.47 \%)$, while treatments of HA +Po.+ Cal. $+75 \%$ NPK, and HA + Po.+ $100 \%$ NPK produced the lowest values (13.00 and14.00) in the first and second seasons respectively. Treatment of HA + Po.+ Cal. significantly gave higher values of T.S.S\% as compared to HA +Po.+ Cal. $+75 \%$ NPK treatment in the both seasons. These results were in partially agreement with that found by Al-Fraihat (2009), Nabil et al. (2010) and Diriba-Shiferaw et al. (2013) Shafeek et al. (2013). The decrease in T.S.S percentage in onion bulbs with the increase in nitrogen supply could be attributed to the increase in moisture contents of the plants. Similar results were obtained by Nabil et al. (2010), Abdissa et al. (2011) and Soleymani and Shahrajabian (2012).

The treatments which contained NPK plus humic acid exhibited higher values of T.S.S \% as compared to NPK alone. Humic acid applications may led to a significant improvement in soil organic matter and improvement of the soil fertility and thus increasing nutrients availability. Hence, it improves T.S.S \%. Similar results were reported by ElDesuki (2004) and Kandil et al. (2013-b). The treatments which contained NPK plus potassium and calcium exhibited higher values of T.S.S \% as compared to NPK alone. Similar results were reported by Ghoname et al. (2007) and Shaheen et al. (2013).

Table 6. Response of bulb quality of onion to foliar spraying with some nutrients under different rates of NPK fertilizers in 2014/2015 and 2015 / 2016 seasons.

\begin{tabular}{lcccccc}
\hline & \multicolumn{3}{c}{$\mathbf{2 0 1 4 / 2 0 1 5}$} & \multicolumn{3}{c}{$\mathbf{2 0 1 5} / \mathbf{2 0 1 6}$} \\
\cline { 2 - 8 } Treatments & $\begin{array}{c}\text { Bulb } \\
\text { Diam. }\end{array}$ & $\begin{array}{c}\text { T.S.S } \\
\text { \% }\end{array}$ & $\begin{array}{c}\text { D.M } \\
\text { \% }\end{array}$ & $\begin{array}{c}\text { Bulb } \\
\text { Diam. }\end{array}$ & $\begin{array}{c}\text { T.S.S } \\
\text { (cm) }\end{array}$ & $\begin{array}{c}\text { D.M. } \\
\text { \% }\end{array}$ \\
\hline Non-fertilization & 4.57 & 14.40 & 13.97 & 4.43 & 14.57 & 11.07 \\
100 \% NPK (Control) & 6.17 & 13.23 & 13.00 & 6.20 & 14.87 & 13.28 \\
HA+100 \% NPK & 6.30 & 13.97 & 13.22 & 6.03 & 16.13 & 13.71 \\
Po+100 \% NPK & 6.20 & 14.03 & 14.05 & 6.33 & 15.97 & 13.15 \\
Cal+100 \% NPK & 6.23 & 14.13 & 13.70 & 6.30 & 16.43 & 13.86 \\
HA+Po+100 \% NPK & 6.07 & 14.30 & 12.56 & 6.40 & 14.00 & 9.58 \\
HA+Cal+100 \% NPK & 6.10 & 14.10 & 13.13 & 6.00 & 15.50 & 12.06 \\
Po+Cal+100 \% NPK & 6.23 & 13.40 & 12.22 & 6.20 & 14.03 & 13.65 \\
HA+Po+Cal & 6.07 & 14.10 & 12.57 & 6.07 & 16.47 & 12.29 \\
HA+Po+Cal+25 \% NPK & 6.27 & 13.87 & 12.99 & 6.13 & 15.10 & 14.33 \\
HA+Po+Cal+50 \% NPK & 6.17 & 13.23 & 13.15 & 6.27 & 15.37 & 13.63 \\
HA+Po+Cal+75 \% NPK & 6.50 & 13.00 & 13.10 & 6.53 & 15.90 & 14.15 \\
LSD 5\% & 0.21 & 0.49 & 1.00 & 0.41 & 1.50 & NS \\
\hline
\end{tabular}

Data in Table (6) show that the highest values of dry matter\% (14.05 and $14.33 \%)$ were obtained from treatment 
of Po. $+100 \%$ NPK in the first season and from the treatment of Po.+ Cal.+HA+25\% NPK in the second season, respectively. While, the lowest values (12.22 and 9.58\%) were obtained by the treatment of Po. + Cal. $+100 \%$ NPK in the first season and by treatment of HA.+ Po. $+100 \%$ NPK in the second season, respectively. Also, it was found that the treatment of Po. $+100 \%$ NPK in the first season and the treatment of Cal. $+100 \%$ NPK in the second season increased dry matter $\%$ as compared to $100 \% \mathrm{NPK}$ alone. Also, the application of $\mathrm{HA}+\mathrm{Po}+\mathrm{Cal}$. Plus $25 \% \mathrm{NPK}$ increased dry matter $\%$ as compared to application of $\mathrm{HA}+\mathrm{Po}+\mathrm{Cal}$. alone. These result may be due to the role of different nutrients on increasing production of assimilates and dry matte\%. Jayathilake et al. (2003) Barakat et al. (2004), Geries et al. (2007), El-Desuki (2004) and Kandil et al. (2013-b) attained similar results.

\section{REFERENCES}

A.O.A.C. (1975). "Official Methods of Analysis of the Association of Official Agriculture Chemists". Twelfth Ed. published by the Association of Official Agriculture Chemists. Washington, D.C. 832.

AbdEl-Al, F.S.; M. R. Shafeek; A.A. Ahmed and A. M. Shaheen, (2005). Response of growth and yield of onion plants to potassium fertilizer and humic acid. Journal of Agriculture Science Mansoura University, 30 (1).

Abdissa, Y.; T. Tekalign and L.M. Pant (2011). Growth, bulb yield and quality of onion (Allium cepa L.) as influenced by nitrogen and phosphorus fertilization on vertisol I. growth attributes, biomass production and bulb yield . African Journal of Agricultural Research, 6 (14):3252-3258.

Al-Fraihat, A. H. (2009). Effect of Different Nitrogen and Sulphur Fertilizer Levels on Growth, Yield and Quality of Onion (Allium cepa L.). Jordan Journal of Agricultural Sciences, 5(2), 155 - 166.

Barakat, M.A.; H.A. El-Katib; S.M. Gabr and E.A. Bedawy (2004). Plant growth characters of field grown onion (Allium cepa L.) as affected by nitrogen application and biofertilizers inoculation. J. Agric. Sci. Mansoura Univ., 29(1): 345-356.

Bettoni, M. M.; A. F. Mogor; V. Pauletti; N. Goicoechea; I. Aranjuelo and I. Garmendia (2016). Nutritional quality and yield of onion as affected by different application methods and doses of humic substances. Journal of Food Composition and Analysis, 5137-44.

Coolong, T.W. and Randle, W.M (2008). The effects of Calcium Chloride and Ammonium Sulfate on onion bulb quality at harvest and during storage. HortScience, 43: 465-471.

Diriba-Shiferaw G.; k. Woldestsadik ;R Nigussie-Dechassa; Tabor and J.J. Sharma (2013). Postharvest quality and shelf life of garlic bulb as infolunceed by storage season, soil type and different compound fertilizers. J. of Postharvest Technology,1 (1): 069-083.

El-Bassiouny, A.M. (2006). Effect of potassium fertilization on growth yield and quality of onion plants. J.of Applied Sci Research, 2(10):780-785.

El-beheidi, M. A.; M.A.I. Khalil; H.E. Arisha and Sabreen Kh. A. Ibrahim (2004). Onion crop response to nitrogen and potassium fertilization and soil application .Hort Dept. Agric., Zgazig Unvi., Egypt Zgazig J Agri. Res., 31(5): 2123-2138.
El-Desuki, M. (2004). Response of onion plants to humic acid and mineral fertilizers application. Annals of Agricultural Science, Moshtohor; 2004. 42(4): 19551964.

El-Desuki, M.; A. R. Mahmoud and M. M. Hafiz (2006-a). Response of onion plants to minerals and bio-fertilizers application. Res. J. Agric. \& Biol. Sci., 2 (6): 292-298.

El-Desuki, M.; M. M. Abdel-Mouty and Aisha. H. Ali (2006b). Response of onion plants to additional dose of potassium application. J. Appl. Sci. Res., 2 (9): 592-597.

El-Tantawy, E.M. and El-Beik (2009). Relationship between growth, yield and storability of onion (Alium cepa L.) with fertilization of nitrogen, sulphur and copper under calcareous soil conditions. Reserch Journal of Agric. Biology and science, 5(4): 361-371.

Esawy M., E. El-Gizaawy and L. Geries (2015). Effect of compost extract, $\mathrm{N}$-fixing bacteria and nitrogen levels applications on soil properties and onion crop. Archives of Agronomy and soil science, 61: 185-201.

Gala, A. A.; Prakash, P.; Umesh Prasad; Swetha Sunkar; N.M.D.S. Krishna; Amit Kumar (2016). Formulation of vermiwash and humic acid and its application on Allium cepa. Biosciences, Biotechnology Research Asia; 2016. 13 (1): 523-529.

Gerasopoulos, D. and P.D. Drogoudi, (2005). Summerpruning and preharvest calcium chloride sprays affect storability and low temperature breakdown incidence in kiwifruit. Postharvest Biol. Technol., 36: 303-308.

Geries, L.S.M.; S. H. Abou Khadrah; M. M.A Tabl; M. A. Gomaa and S. Gh. R. Sorour (2007). Effect of different fertilizer sources on growth and yield of onion (Allium cepa L.). Doctor of Philosophy, Agronomy Department of Agronomy Faculty of Agriculture Kafrelsheikh University.

Ghoname A., Z.F. Fawzy, A.M. El-Bassiony; G.S. Riadand, and M.M.H.Abd El-Baky (2007). Reducing Onion Bulbs Flaking and Increasing Bulb Yield and Quality by Potassium and Calcium Application. Australian Journal of Basic and Applied Sciences, 1(4): 610-618.

Hafez, M.M. (2003). Effect of some sources of nitrogen fertilizer and concentration of humic acid on the productivity of squash plants. Egypt J. Appl. Sci., 19(10):293-309.

Haleema, M. S. B.; M. Zamin1, R. Alam and H. Zada (2012). Humic acids affect the bulb production of onion cultivars. African Journal of Microbiology Research, 6(28): 5769-5776.

Hepler P.K., (2005). Calcium: a central regulator of plant growth and development. Plant Cell.,17: 2142-2155.

Islam M. K.; M.F. Alam and Islam A.K.M.R. (2007). Growth and yield respin of onion (Allium cepa $\mathrm{L}$.) genotupes to different levels of fertilizer .Bangladish J.Bot., 36(1): 33-38.

Jayathilake, P.K.S.; I.P. Reddy; D. Sriharai; G. Neeraja and R.Reddy (2003). Effect of nutrient management on growth, yield and yield attributes of rabi onion (Allium cepa, L.). Vegetable Sci., 29(2): 184-185.

Kandil A.A., A. E. Sharief and F. H. Fathalla (2013-a). Effect of organic and mineral fertilizers on vegetative growth, bulb yield and quality of onion cultivars. Sci. J. Crop Prod. 2(3): 91-100. 
Kandil, A. A.; Sharief, A. E.; F. H. Fathalla (2013-b) Onion yield as affected by foliar application with amino and humic acids under nitrogen fertilizer levels. Sci. Journal of Crop Production; 2013. 2(2): 62-72.

Khalil, F.A.; A.S. Abo El-Hamd; E.I. Mohamed and M.A.M. Hassen (2002). Response of onion crop var. Shandaweel 1 to some sources of organic fertilizers. Assiut J. Agric. Sci., 33(5): 73-83.

Lester, G.E. and J.L Jifon, (2007). Foliar applied potassium: Effects on cantaloupe quality. Acta Hort., 731:115-120.

Marschner, H. (1995). Mineral Nutrition of Higher Plants. $2^{\text {nd }}$ Ed. Academic Press. London, UK.

Mengel, K. and E. Kirkby, (1980). Potassium in crop production. Adv. Agron., 33: 59-110.

Miah, M.K; M.A. Siddique; M.A. Hossain and M.A. Salam(2005) .Effects of plant spacing and nutrients on the growth and yield of onion. Journal-of-SubtropicalAgricultural-Research-and-Development, 3(2): 50-59.

Mohamed, G.A. and A.A. Hemida (2004). Response of Giza-6 Mohassan onion to some irrigation and nitrogen fertilization treatments. Minia J. of Agric. Res. \& Develop, 24(2): 177-190.

Mohanty, B.K. and J. N. Das (2001). Response of Rabi Onion cv. Nasik Red to nitrogen and potassium fertilizer. Indian Society of Vegetable Science, 28(1).

Mondal, S.S.; D. Archarya; A. Ghosh and U. Thapa (2004). Integrated management of organic and inorganic sources of nutrient to improve productivity and qualitative characters of rice and onion in rice-onion cropping sequence. Environment and Ecology, 22(1): 125-128.

Morsy, M.G.; R.A. Marey; S.S. Karam and A.M.A. AboDahab (2012). Productivity and storability of onion as influenced by the different levels of NPK fertilization. J. Agric. Res. Kafer El-Sheikh Univ., 38(1) 171-187.

Mozumder S.N.; M. Moniruzzaman and G.M.A. Haliim (2007). Effect of $\mathrm{N}, \mathrm{K}$, and $\mathrm{S}$ on the yield and storability of Transplanted onion (Allium cepa L.) in the Hilly Region. J.of Agri. And Rural Development Gazipur, 5(1/2): 58-63.

Nabil, G.; A. Rab; S.J. Abbas; M.F. Farhatullah; F. Munsif and I. H. Shah (2010). Influence of different levels of potash on the quantity, quality and storage life of onion bulbs. Pak. J. Bot, 42(3):2151-2163.

Nasreen S, M.M. Haque, M.A. Hossain, A.T.M. Farid (2007). Nutrient uptake and yield of onion as influenced by nitrogen and sulphur fertilization. Bangladesh J. Agric. Res., 32(3): 413-420.
Sangetha M. and P. Singara (2007). Effect of lignite humic acid and inorganic fertilizers on growth and yield of onion. The Asian Journal of Soil Science 2 (1): 108-110.

Shafeek, M. R.; M. K. Hassan Nagwa; S. M. Singer and H. M. EL-Greadly, Nadia (2013). Effect of potassium fertilizer and foliar spraying with Etherel on plant development, yield and bulb quality of onion plants (Allium cepa L.). Journal of Applied Sciences Research, 9(2): 1140 - 1146.

Shaheen A. M.; Fatma A. Rizk; S. M. Singer and S.O. El-Abd (2013). Onion Productivity as Affected by Foliar Spraying of $\mathrm{Ca}, \mathrm{Mn}$ and $\mathrm{Mg}$ as Individual or Mixed. Middle East Journal of Applied Sciences 3(3): 113-121.

Shaheen, A.M., Fatma A. Rizk, A.M.M. El-Tanahy and E.H. Abd El-Samad (2011). Vegetative Growth and Chemical Parameters of Onion as Influenced by Potassium as Major and Stimufol as Minor Fertilizers. Australian Journal of Basic and Applied Sciences, 5(11): 518-525.

Sheng-li, H.E.; X.U. Wan-li; M.A. Hai-gang, J.I.A.N.G. Chen-yi; S. U. N. Hao-wen, C.A.L. Ze-yu (2010). The impact of humic acid fertilizer on yield and quality of onio. Xinjiang Agricultureal Sciences, 6.

Singh, R. B.; Singh, S. B. (2000). Significance of nitrogen, phosphorus and potassium on onion (Allium cepa L.) raised from onion sets (bulblets). Indian Society of Vegetable Science, 27(1): 88-89.

Snedecor, G.W. and W.G. Cochran (1973). Statistical Methods $6^{\text {th }}$ Ed. Iowa State Univ. Press, Ames., Iowa U.S.A. pp.593.

Soleymani, A. and M. H. Shahrajabian (2012). Effects of different levels of nitrogen on yield and nitrate content of four spring onion genotypes. International Journal of Agriculture and Crop Sciences. 4(4): 179-182.

Waller, R.A. and D.E. Duncan (1969). A bay rule for the symmetric multiple comparison problem. Amer. State Assoc. Jour. Dec., 1485-1503.

White, Philip J.; Broadley, Martin R. (2003). Calcium in Plants. Annals of Botany. 92(4): 487-511, October 2003.

Williams, L. and U. Kafkafi, (1998). Intake and translocation of potassium and phosphate by tomatoes by 24 late sprays of KH PO (MKP). In: El-Fouly, M.M., F.E. Abdalla, and A.A. Abdel-Maguid (eds). Proceedingof the symposium on foliar fertilization: A technique to improve production and decrease pollution, 10-14 Dec.1995, NRC, Cairo, Egypt.

Yaso, I. A.; H. S. Abdel-Razek and M. A. Wahb-Allah (2007). Influence of biofertilizer and mineral nitrogen on onion growth, yield and quality under calcareous soil conditions. J. Agric. and Env. Sci. Alex. Univ. 6 (1): 248-267.
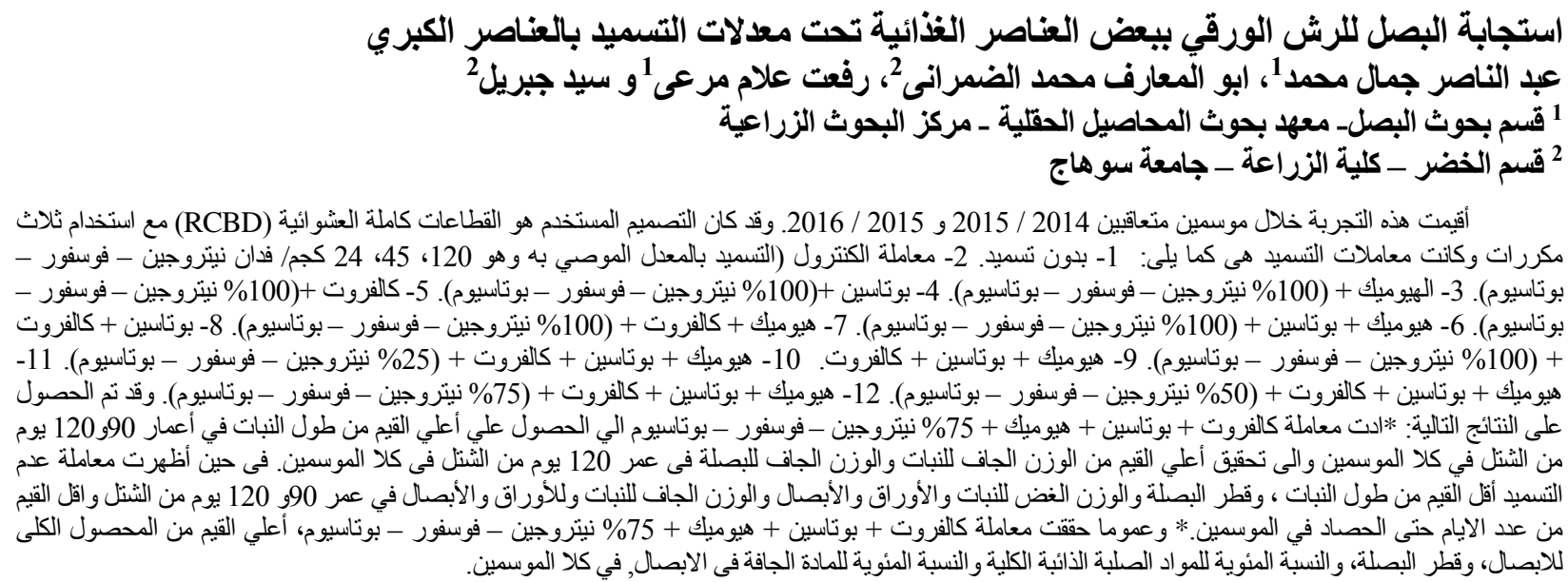